\title{
LIVING THE LAUGHSCREAM: Human Technology and Affective Maneuvers in the Iraq War
}

\author{
NOMI STONE \\ Princeton University \\ (D) http: / / orcid.org/0000-0001-5428-6815
}

Over a tiny bodiless coffin in an isolated American wood, Iraqi role-players are wailing inconsolably. In a cultural training simulation some military contractors call "The Crying Room," the women congregate around a small wooden coffin decorated with a bouquet of fake flowers, a framed picture of a child ("the deceased"), and a black hijab-cloaked Barbie, for regional flair. The women have howled with grief dozens of times, performing for three days straight, for each new rotation of training U.S. soldiers. Their voices are hoarse. "I sound like a donkey," one of the women laughs, mimicking a braying noise. The simulation always starts the same way: the Qu'ranic recitation begins to play from a boom box; the role-players, clad in embroidered black dresses and veils much like the doll's, wail and hit their thighs and the tops of their heads in synchronicity. Once, when they are testing the music, a military contractor walks into the room and playfully begins to dance to the reedy lilt of the Qu'ran, but one of the roleplayers chastises him: "That's God music!"

In the scenario, the U.S. soldiers had inadvertently crushed the child with their tank and now must pay their condolences, while ideally acquiring intelligence about the family's connections to the militia. When the soldiers enter a cultural simulation, the first step in the training program is to establish rapport by assuming sympathetic postures and mirroring their interlocutors while their interpreters translate; in this particular room, they are often flustered by the cacophony of 
Arabic and weeping and seek to regain their composure. ${ }^{2}$ Several units of soldiers are training at once, and it is easy to hear the adjacent clamor: tea glasses clinking in one room; a thump and a scream in another. In each room, Iraqi role-players are hired to enact mourning or bargaining, chatting or suffering, as Arab Others might. They act out a kaleidoscope of archetypes: Corrupt Mayor; Insurgent; Imam; Mourning Mother, with correlating props: küfiyyah scarves, billowing robes, teapots, posters of militia leaders, prayer rugs. If the military personnel believe the training soldiers have engaged incorrectly with the wartime local, they pause the game to discuss the lesson; then they reset and begin again, as if within a well-coordinated machine with movable parts.

In forests, fields, and deserts across the United States, in what has been called a "hidden archipelago of mini-cities" (Graham 2007, 122), American soldiers arrive at mock Middle Eastern villages to train their bodies and imaginations for war before deployment. Middle Eastern role-players, many of them recent war refugees from Iraq and Afghanistan, are salaried for their labors and repetitively act out the contingencies of war for the training soldiers. Drawing on twenty-six months of ethnographic fieldwork in the extended Iraq warscapefrom predeployment exercises in mock Middle Eastern villages across the United States to Iraqi refugee neighborhoods in Amman, Jordan-I examine the contours of the wartime work outsourced to populations I call human technologies: individuals construed by the U.S. military as embodied repositories of cultural/regional knowledge. These individuals act as local mediators, translators, advisors, and proxies for U.S. military personnel and produce soldiers as insiders in the war zone: they are hired to augment both U.S. military access within the war zone and soldiers' understanding of the so-called human terrain. I examine in this article how an ironic disjuncture between military prescriptions for authenticity and roleplayers' experiences of inauthenticity generates moments of charged incongruency for those hired to embody constricted versions of their cultures. I argue that a charged tension manifests itself in the training apparatus: on the epistemological level, even as they experience excess, role-players work to make the simulations "look good" to retain their jobs; meanwhile, that excess manifests affective overflow - in particular, one form that a role-player called "the laughscream." I contend that such moments of affective excess create a momentary reprieve for roleplayers while typically not disturbing the military structure.

I focus here on Iraqis, many of whom worked as interpreters or contractors for the U.S. military during the 2003 Iraq War, and who, on emigration to the United States, began to work as role-players in predeployment simulations. Newly 
arrived Iraqis typically learned by word of mouth from other Iraqis of lucrative contracts as cultural role-players. These jobs were highly desirable for a population trying to get economically situated in a new country, and proved especially popular among those with prior U.S. military affiliations. Meanwhile, although they were employed to enact exemplars/archetypes of their cultures, these individuals conversely have inhabited a particularly precarious margin: they were frequently ejected to the peripheries of their own societies as traitors by their compatriots and as potential spies by U.S. soldiers, and in some periods during the war, the less fortunate were unable to procure the U.S. visas that would save their lives. ${ }^{3}$

\section{WEAPONIZING CULTURE}

Contemporary anthropologists of militarism have pointed to the post-9/11 expansion of the U.S. security state, in a climate of uncertainty where nonstate adversaries have been less legible to the military. Amid heightened and ongoing war preparedness (Lutz 2001; MacLeish 2015), Joseph Masco (2014, 19) describes the U.S. military's attempt to "secure life from the species to the population to the individual to the microbe." In this logic of encompassment, the U.S. military has increasingly weaponized new technologies for understanding motivations and patterns of adversaries - in this instance, other human beings.

The wartime intermediaries described herein form part of what has been called the U.S. military's cultural turn, that is, the use of culture (in the form of immersive trainings, rubrics, and local advisors) in a strategic attempt to understand, pin down, and make legible a post-Cold War adversary imagined as increasingly opaque. According to military theorists, the notion of culture-centric warfare emerged after U.S. military disillusionment with its 1990s Revolution in Military Affairs, which had focused on new technologies and conventional environments. This shift to cultural literacy to apprehend the adversary inflected counterinsurgency studies and escalated as a framework after 9/11. ${ }^{4}$ In 2006, the U.S. Army and Marines coauthored Field Manual 3-24 under General David Petraeus, reconceptualizing the 2003 Iraq War as a counterinsurgency and sowing the seeds for culture to serve as the new hermeneutical mechanism that separated insurgents from the general population. Meanwhile, the U.S. military hired anthropologists to embed within combat units to provide so-called conflict ethnographies for the Human Terrain System (HTS). The military analyst and HTS senior social scientist Montgomery McFate (2005, 48) explained the use of cultural strategies: "The more unconventional the adversary and the further from Western 
cultural norms, the more we need to understand their society and underlying cultural dynamics.”

Simultaneously, local wartime intermediaries were hired to formally or informally assist soldiers in acts of seeing, knowing, and translation: namely, differentiation between adversaries, potential allies and proxies, and the population. This twenty-first-century military focus on culture emerged in tandem with privileging posthuman technologies to extend optical reach, such as unmanned aerial vehicles and more pervasive surveillance. Amid U.S. military technophilic fantasies of omniscience — what Paul Virilio $(1989,2)$ calls "ubiquitous, orbital vision of enemy territory" - local wartime intermediaries emerged as militarized bodies to see the intimate unseen, to translate and furnish otherwise inaccessible, operationally useful cultural knowledges, and ultimately to produce the U.S. soldier as an insider within the war zone.

Critics of the U.S. military's cultural turn have pointed to what Ann Stoler (2002) calls the "intimate" gaze in the consolidation of power, particularly in neo/ colonial contexts. The military's culture projects have indeed entailed diagramming social structures and harnessing information about social patterns and motivations: the sphere of Stoler's intimate. As Stoler (2002, 8) asserts, such classification is "not a benign cultural act but a potent political one." Many scholars, in particular, anthropologists, have focused on how such knowledge is used to manage populations in wartime, as well as in intelligence and adversary targeting (Gregory 2008; Price 2009; Kelly et al. 2010), critiquing the use of culture as a "weapon system" (Davis 2010, 8). Maximilian Forte (2011, 151) describes how anthropologists challenged the possibility of military cultural programs supporting ethical research, and contended that "counterinsurgency can never be humanitarian." The American Anthropological Association Executive Board (2007) condemned the HTS program as an "unacceptable application of anthropological expertise," and the military terminated it in 2014. However, another facet of the cultural turn, the use of role-players in cultural simulations, continues.

\section{THE HUMAN TECHNOLOGY}

When I was observing military trainings, I overheard a major in charge of the exercises describe the cultural role-players as "the apparatus" to one of his colleagues. I had already noticed how these individuals were maneuvered within particular parameters — what the military called "left and right limits," as if there existed spatial coordinates that they were not permitted to transgress. Although such limits were also applied to training soldiers and to all employees, military 
personnel used especially mechanistic jargon to describe Iraqi role-players. They were regularly referred to as an operationally useful training tool, a tool requiring limits and coaching to enable maximum efficacy. This metaphorization in relation to machines led me to consider how these individuals were conscripted as something akin to human technologies, as they alternately must constrain and produce knowledge and affect, within military parameters. I conceptualize human technologies as modern technologies in Martin Heidegger's $(1982,17)$ sense as "standing-reserves" of extractable cultural know-how, who are "good-for" mediating, translating, and acting as proxies within unknown terrain in wartime. In this logic, as humans order, use, and exhaust the energies of nature, ultimately they are transformed into usable resources. My notion of the human technology is also inspired by Karl Marx's (2011, 462) critiques of man as a $\operatorname{cog}$ in a capitalist machine, describing how the worker becomes a "living appendage" in the modern industrial factory. ${ }^{5}$

In this case study, human technologies are hired to extend the gaze and agency of the soldier and render him or her an insider within an unknown culture to facilitate wartime projects. Kenneth MacLeish $(2012,7)$ contends that "the military body is not just a 'tool of man,' to use Marcel Mauss's words. It also represents the transformation of men and women into tools." Soldiers too might be understood as technologies in this sense, as human resources-bodies and minds harnessed for their wartime uses - but I focus here largely on the hitherto undescribed militarized bodies and selves of their intermediaries who are deployed as cultural tools. Recent anthropological literature has richly documented militarized worlds and subjectivities, with a focus on soldiers (Der Derian 2001; Gutmann and Lutz 2010; MacLeish 2015; Wool 2015); I complement that literature, capturing the complex and overlooked phenomenology of the experiences of Middle Eastern intermediaries incorporated into U.S. war.

In this article, I will trace the processes that unfold as military personnel seek to deploy cultural intermediaries as wartime technologies to produce U.S. soldiers as insiders in the war zone - as well as query the limits of that project. I offer the analytical conceit of the human technology cautiously, with caveats about the risks of the representation therein. I critique here the ways in which wartime intermediaries are militarized as tools, while seeking at all costs to avoid complicity in that reifying discourse. Rather, these individuals are, like all others, both confined by structures and capable of making choices in the world. In cultural trainings, military personnel maneuver role-players within mechanized logics and discourses. Through an examination of the epistemological and affective labors 
these wartime intermediaries perform, this study illuminates how the intrinsic contradiction in the term human technology - the turning of person into machine for a singular use and foreclosing other forms of being and becoming-plays out on the ground. Moreover, while scrutinizing military representations and epistemologies, my intention is not to comment on their authenticity so as to modify or improve them, but rather to critique the underpinnings of the military project as a whole in an ethical, political, and epistemological gesture.

In recent decades, social theorists have shown affect's role in subjectivity, action, and agency, emphasizing the autonomy of the body in its interface with the world (Massumi 1996) and how "people are quite literally charged up by the sheer surge of things in the making" (Stewart 2005, 1041). William Mazzarella $(2009,299)$ notes that any social project not driven by force "must be affective in order to be effective." Recently, some anthropologists have read affect as a means of "creating new subjects and relations between subjects," in some instances offering the potential for "contemporary political and economic transformations" (Richard and Rudnyckyj 2009, 62). Others have pointed instead to affect's role in driving social reproduction and reinforcing norms (Berlant 1997; Adams 2013).

I conversely look at an instance in which affect, in this case laughter, may enact a moment of microtransformation for the person laughing, but with little impact on the training structure-ultimately neither subverting nor reinforcing it. While affect is crucial in recuperating constrained subjectivities, the structure nonetheless appears to continue mutely, with military systems and notions about the world undisturbed. The role-players' laughter existentially negates the possibility that human beings can truly be tools, while indicating that, in practice, they can, however, somewhat effectively serve as tools. In my conclusion, I nonetheless consider how that laugh might ripple beyond, forecasting unpredictable future possibilities.

\section{FROM THE WAR THEATER TO WAR AS THEATER}

This study focuses on Iraqi role-players in the United States, many of whom are 2003 Iraq War asylum-seekers. The majority of these individuals worked as interpreters or contractors for the U.S. military at some point between 2003 and 2011 and, due to their wartime affiliations, can no longer return to an increasingly violent Iraq. Current estimates suggest that somewhere between thirty thousand and one hundred thousand Iraqis worked directly for the U.S. military, government, media, contractors, and subcontractors during the 2003 Iraq War as interpreters, contractors, fixers, and bodyguards. ${ }^{6}$ Many more Iraqis assisted the 
Americans informally by giving them tips or stabilizing their districts and villages as government functionaries.

Iraqis chose to work for the U.S. military in Iraq for a panoply of ethical, political, and economic reasons, which were compounded by more contradictions as popular resistance to the war increased. These Iraqis were usually young and somewhat educated, motivated by a complex range of ideological and economic interests. Many described experiencing political or sectarian marginalization under Saddam Hussein's regime: some hoped to contribute to political change under the Americans, while others spoke of pain at the occupation, but admitted to still needing the work. One former interpreter explained: "I had a mixed reaction to the invasion. The Saddam period was bad for everyone." Most described enthusiasm about new work opportunities, the possibility of visas, and a better future. According to many, as U.S. military promises remained unfulfilled and Iraqi resistance to U.S. presence grew, their own positions, increasingly perceived as those of collaborators, became more dangerous and complex. Another former interpreter elaborated: "I feel betrayed by my country. They feel like I'm a traitor, that I betrayed them. But I feel betrayed. I was trying to help them. I thought I was changing [Iraq] for the better."

For Jean-Paul Sartre (2008, 57), the collaborator suffers from "historicity" and "ratifies events simply because they occur," seeking to side with the victor and thereby ascend after the war. In contrast, I believe that many of the Iraqis employed by the U.S. military lived a more morally complex form of history, often imagining making a contribution to a thriving future Iraq. Nonetheless, as Iraqi resistance to U.S. occupation grew, the Iraqis I interviewed described how they faced increased accusations of being informants to the U.S. military. My interlocutors described how this climate of accusation imperiled them, especially amid heightening sectarian violence in 2006, eventually propelling the departure of many from the country.

In 2011, I began formal fieldwork in what I describe as the extended Iraq warscape, stretching from U.S. military simulations to Iraqi refugee neighborhoods in Amman, and crisscrossing through military institutions of Washington, D.C. I eventually honed my study to focus on Iraqis who first worked for the U.S. military in Iraq and then served in predeployment simulations as role-players in the United States. As in their prior work in Iraq for the U.S. military, they were drawn to simulation jobs for a range of reasons: the majority whom I spoke with, trying to get established in a new country, were lured by well-paying contracts available to Arabic speakers. As one role-player explained: "It's really 
good money, and we're trying to get settled in the U.S." Some expressed a double patriotic impetus, hoping to serve their new country by assisting the U.S. Army with Middle Eastern knowledge, and thereby helping the Middle East - and meanwhile working to counteract American stereotypes: "I want to give them a real picture of us. We're not bad. We're a peaceful people.” Others expressed internal contradictions about their chosen work, which I explore in other writings (Stone 2016). Most sought military contracts while holding down other jobs, from construction labor or work in the service industry to teaching Arabic on the side. Some sought to establish themselves in the United States, while others imagined returning to the Middle East after securing the privileges of U.S. citizenship.

\section{EPISTEMOLOGIES}

As military personnel mobilized cultural knowledge as a means of understanding human terrain in the war zone, there was an ongoing commitment to preparing soldiers for "the real thing," or what they called the "ground truth: downrange." One military instructor explained of the training: "You must make it real." Another involved in crafting simulations who had previously been deployed in Iraq noted: "The other night with the Arabic music going and people talking and the fire going, it transported me back to Iraq. It was dark. I was reaching for where my weapon would be." Given this imperative, cultural representations of the Middle East were shoehorned into specific conceptions of authenticity. In some cases, these representations subtracted history and politics from lifeworlds, mirroring Talad Asad's (1983, 251) critique of Clifford Geertz for forging "an a priori totality of meanings, divorced from the processes of formation and effects of power." One afternoon, a military contractor invited me to the prop warehouse. As I waded through apparently bloodied knives and shimmering Middle Eastern cloth, the contractor described his philosophy behind cultural training: "You do the best you can to make it look the part. But the inside, what the role-players are trying to replicate (language, culture, norms), that's the most important." I asked him if these performances, this inside, happened organically. He replied: "Over time, the role-players are further away from being in-country. People come to us and they are trying to assimilate here, and we want them to act like they haven't assimilated. You have guys like [our cultural advisor] to take them back.”

Amid this interest in authentic — or, indeed, synchronic (apolitical/historical)_ cultural knowledge, military supervisors also frequently emphasized the importance of keeping all aspects of the simulations within objectives, or in the 
previously noted military lingo, "left and right limits." Role-players were coached to operate within these limits and not to add anything extraneous. Thus, although role-players understood themselves as subject-matter experts on the Middle East, granular cultural knowledges often remained exterior to the parameters of tactical military training objectives, creating ongoing confusion for some about expectations.

As they were instructed on left and right limits, those mechanistic parameters for action, Iraqi intermediaries were asked to supply only the particular cultural representations solicited by military personnel - and nothing in excessfor consumption by the training soldiers. Role-players receive preparatory materials to help them hew to these simulation objectives, for instance, a country or village study, describing the geopolitical situation of the fake (Middle Eastinflected) world they are about to enact. The specificity of the scripts varies. Roleplayers with supporting roles are often just given their name, tribe, place of origin, profession, and sympathies (pro/anti-American), and sometimes a list of requests to put to the Americans (e.g., water or medicine). Those cast as key leaders, such as the people embodying a mayor or an imam, typically receive more detailed scripts, with specific lines. Depending on the base and the exercise, scripts are typically written by outside contractors (many of whom are former military personnel), by the majors running the exercises for their teams, or in collaboration; scripts were balanced between specific training objectives and a desire to incorporate lessons learned from military personnel in the field. Scripts were also always in motion: for example, if trainees made an error, such as failing to identify an adversary, their instructors would turn up the heat to teach them a lesson, adding extra hours of explosions the next night.

One of my military interlocutors who helped devise scripts explained the parameters for role-players: "Role-playing is an effective training tool, as long as it's used appropriately and in accordance with the training objectives and doesn't get off to something crazy, which happens." In another instance, a contractor overseeing the role-players announced: "This should be real but controlled. Not spontaneous ad-libbing. We can turn up the heat and complexity, but that must be controlled."

I demonstrate here that although cultural intermediaries were construed by American military communities as sources of authentic cultural knowledge, in practice, role-players were maneuvered as cultural tools within military left and right limits that emphasized being over knowing. Meanwhile, role-players were continuously reminded that they are in fact not "being themselves," but rather 
embodying specific constructions of their countries of origin. I show how the role-players negotiated their positions, as well as the ultimate military production of compliant human technologies - that is, individuals who were meant to enact Middle Eastern knowledge in a particular way and for a specific purpose — without injecting disruptive excess into the military training.

American military leadership and training soldiers frequently emphasized the importance of learning about Middle Eastern culture as a component of their preparations for war. When asked why Middle Eastern role-players were necessary in this pursuit, many described those individuals as a metonymic access point to the region: "The role-players are a whole group of Arabs in order to understand the Arab world at large." A captain helping his team train explained: "The roleplayers are just playing themselves! They're just being a different culture!"

Despite the ontological primacy the military assigned to them, many roleplayers described the ambiguity of their epistemological position as proprietors of culture-but not on their own terms. In this constellation, role-players became embodied technologies of being Arab, rather than of knowing or translating anything particular about the Middle East. In this sense, the position of the roleplayers echoes a colonial logic of cultural translation, wherein the actual knowledges of the Other are not necessarily pertinent. Following Edward Said (1978), Western knowledge production about the East demonstrates more about the paradigms of the seer than about those of seen. Military cultural logics fluctuated from converting fluid forms of cultural difference, such as tribe or Islam, into ossified cultural categories to imagining highly contingent, unpredictable, yet ultimately containable behavior (e.g., that of the "wily" Arab). Talal Asad (1986, 163) notes the epistemic violence intrinsic to the metaphor of cultural translation, explaining that the practice is "enmeshed in conditions of power," and thereby usually occurs unidirectionally, from East to West, to be consumed by Western readers. Likewise, cultured bodies were hired to help the military culturally translate others - that is, imagine, categorize, and manage them.

As cultured bodies required to operate within left and right limits - more akin to translated texts than cultural translators - role-players wrestled with uncertainty about their epistemological positions. One role-player, Mahmood, explained: "Sometimes [the soldiers] don't listen to me. You're trying to teach them culture, and you have no say in it. [The culture is] mine. I'm here for you. Not for myself." Role-players alternately described culture as "their own" and as a "product" they were offering to the military, trying to understand what this ambiguity meant for the roles they were expected to enact. 
This tension between proprietorship and the offering of a service continuously coalesced around questions of representing culture authentically. Meanwhile, the finer points of culture were often subsidiary to the efficient practice of tactics for military personnel, in some cases creating the impression of troubling cultural inauthenticity for the role-players. In fact, ultimately and ironically, roleplayers hired for their cultural authenticity were required to act in ways they considered inauthentic. One role-player, Salem, described culture as a product they were offering, and expressed frustration when the roles and scenarios the military gave them impaired that product: "We have to provide service the right way. You have a customer. The customer wants it perfect. Why is a Kurd roleplaying an Arab? Even his Arabic language is not correct." In another instance of compromised authenticity that startled the Iraqis, they were hired to role-play Afghans, as the military contractor could not locate enough Afghans. Another role-player, Lubna, shared her indignation over the inauthenticity of the settings of the simulations, as well as the hiring of role-players across nationalities: "There is no resemblance. Even the rocks are different. This place is full of Egyptians. Why don't they make a better resemblance? I was angry about this. I told the captain." Another role-player spoke of her frustration from the confines of her particular role: "I had so many things I wanted to say to them, and I couldn't! I wanted to say: there are no services - no electricity, no water; there are explosions. We are afraid. If you have experience, you should be able to say it!” Yet amid these frustrations, role-players most typically focused on image management, making the simulation run smoothly and "look good" even as they recognized inauthenticity - in order to retain their work. For example, Yusuf cautioned other role-players not to diverge from the script: "Sometimes you can add a little, but be careful. If you add one word, you could change the whole scenario." Indeed, when role-players found scenarios incorrect or artificial, they often kept silent. Yusuf told me: "I wouldn't tell them they're doing something wrong. I would cover for them if there's a mistake. That's why they promoted me to sergeant in the scenario." Hussein added: "No one speaks up. No one stands up for anyone but themselves. We want to keep our jobs.”

In certain circumstances, military and/or contractors did welcome interventions into the simulations. Sometimes a role-player was appointed cultural advisor and took on a range of roles, from procuring props to assisting in roleplayer hires. One such individual, when asked if he relayed the other role-players' suggestions to his boss, explained: "I take ideas. I go with it if it's right. I have to confirm with the Army." Occasionally, the cultural advisor would become an 
informal advisor to military personnel and was urged to intervene when he believed the scenarios were incorrect. One such cultural advisor, Ghaith, sought to improve the scenarios within the simulations whenever he could. He recounted:

In one scenario, there was a fake election. An elderly role-player walked in - the soldiers didn't search him. I asked, why didn't you? The soldier said, "they told us not to because he is older and needs respect." I said: "I don't give a damn about culture when it comes to safety. Does this guy have a [suicide] belt on him?"

Ghaith spoke from a perspective attuned to military concerns, suggesting that overemphasis on cultural details might blind soldiers to tactical or security issues. He explained that he felt affirmed in his correction by that same soldier, who later returned from a deployment: "The soldier told me he benefited so much from [the simulation]. He was in Iraq for nine months afterwards." Ghaith was confident in the utility of his knowledge, emphasizing the importance of the training in preventing the soldiers from making mistakes: "In each [training], the commander must sign off if a unit is ready or not to deploy. Sometimes they have to repeat the training. This stuff is not a joke." Ghaith was proud of his role: "The scenarios were not accurate, and that's why we were there."

Ghaith had the ear of an American commander, but such relationships were rare. More commonly, role-players were reticent to interject their own knowledge. Indeed, there are consequences for exceeding left and right limits. For example, although religion and politics were regularly woven into the scripts in precurated forms (the object of many simulations was to determine the adversary), role-players were told to "never bring religion or politics into the box" on their own. This prohibition made the boundary between inside and outside "the box," and the contrast in behavior in each space, all the starker. A military contractor told me that this was because the soldiers were being videotaped and should not be prompted to express political opinions while in uniform. However, roleplayers at one of the bases told me that this rule had been more firmly enforced after fistfights prompted by religious and political provocations had broken out among them.

In one instance, while I was role-playing a villager in a fictional Middle Eastern country, I sought to test those parameters. I was dressed like the Iraqi role-players, in a long robe and a hijab. We were told to practice Modern Standard Arabic with the soldiers and engage in basic conversation, entailing more free play than usual. We were given a description of the fake Middle Eastern country 
that had been occupied by the American military and the basic story line: we were meant to discuss the needs of our village with the soldiers. I was cast as a teenage girl who wanted to study abroad and was seeking information on furthering my studies from the soldiers. During the role-play, I brought into conversation one religious and one political topic. I first asked the soldiers if there were Muslims in America, and if they were religious. Salem, the Iraqi cultural advisor, hissed "cut" from the corner, whispering to me in Arabic à'ifi (sectarian), even though nothing in my query had actually referred to sectarianism. He then summoned me, explaining: "There is no religion in the scenario." I next asked a soldier why the United States could have nuclear weapons but no other countries could. Salem again called me out of the role-play: "No politics in the scenario."

At this point, everyone took a break, and the role-players cautioned me never to bring up "real topics" in the simulations - that is, to keep things running smoothly, or otherwise imperil one's job. Thereafter, I sat on the steps of the collapsible home with Hussein, another role-player, and, following our usual pattern, we immediately began to discuss religion and politics. He recounted how religio-political dynamics, in the form of a sectarian death squad, had nearly cost him his life. He was on a bus in Baghdad when a militia stopped the vehicle and asked everyone their sect: "My friend was standing in front of me. He didn't know the right answer to the question. He replied Shia. But it was the wrong answer: the men shot him.” Hussein, who has a classically Shia name, but is in fact half-Shia and half-Sunni, answered that he was Sunni. When they asked why he had a Shia name, he replied: "Well, I really am Sunni." He recounts: "Then they said, well, you're white [noting that Sunnis from Baghdad were often palecomplexioned, while Shia from the south often had darker skin], so we won't kill you."

After this harrowing story, Hussein and I returned inside for the "cultural lunch," which functioned as an ongoing portion of the simulation. As a female role-player, I spooned out the soldiers' couscous. We then sat in a circle and volleyed benign questions in formal Arabic to the soldiers, asking about what they liked or did not like. The surface of the scenario was taut, a translated text neutered of danger. Hussein offered to the circle: "Do you like grapes?" (Hal ta'jibūn al-'anib?). Such banality and controlled discourse coexisted with the intensity on the stairs. As the role-playing individuals cleave to military parameters, they must efface the surplus of their experience and knowledge, assimilated as regulated and functioning technologies made docile, and through which military discourses flow. Yet ironically, amid the military hiring of cultured bodies to 
perform themselves, these individuals enacted cultural constructions they often considered inauthentic: in these instances, they stood not within themselves but beside themselves, observing the effacement of their own lived experiences: culture in its pure version, extracted out of history and politics.

\section{AFFECTIVE MANEUVERS}

I have argued that military constructions of the Middle East generate moments of epistemological excess and incongruency for role-players, even when they do not express these disjunctures. I now trace the quite different outcomes when they experience affective surplus. As in their mediation of role-players' knowledge, military personnel provide certain parameters for affect, encouraging some affective intensities as registers of the authentic and dissuading others as charged distractions. Yet whereas military personnel largely curtail or even efface role-players' epistemological excesses in favor of more rigid cultural translations, charged affective surpluses take on a range of other contours. In some instances, affect seems to act, jolting into a controlled field, and offering a changed experience for the person experiencing it.

The present loss of Iraq exists in constant tension with the Iraqi role-players' daily lives in the simulations, spaces of uncanny and often mechanical repetition, which can evoke the real for some. This continual affective experience occasionally generates a surplus, which erupts in multiple potential vectors, through the tears of falling into the simulation or else laughing against it, especially via what one role-player called "the laughscream." For example, enacting a fake funeral, as a group of role-players carries the mock coffin, quite suddenly their performed lamentation morphs instead into screaming commingled with suppressed laughter. The affect is contagious, but if their supervisors are watching, they return to more stylized mourning or cover their faces with their veils. The laughscream, as I will later describe in more detail, resituates the role-plays as artifice and acts as a charged refusal for the role-player: both of a mechanistic form of action and of a continued inhabitation of wartime precarity.

As noted, the performance of affect, like that of knowledge, is subject to military left and right limits. Similarly, authenticity is viewed favorably, and military personnel and contractors ask role-players to perform storylines as authentically as possible. Indeed, intense performances are seen as authentic and applauded by military employers, and some role-players assert that such performances enable them to get rehired. Lubna describes generating emotion among the others: "Once I got everyone crying. I told them, pretend it's someone 
you love. We began to cry, all of us. Amal began to cry and couldn't stop." She was rewarded for this intensity by her employer: "They gave her a special coin to thank her." While military coins create an economy of honor and gratitude, the moment also inscribes affective performances into a commodity logic. Meanwhile, although such intensities are encouraged by military contractors in the putatively safe expression of grief, in some instances, they are interrupted if they move into the volatile expression of rage. For example, Amal cried earnestly without being able to stop and was honored. On a different occasion, in a roleplay, Ahmed stared at an American soldier with apparent fury, causing a spontaneous fistfight between the two. Rather than inscribing the moment within the plausible simulacral, he was told by his employer to control himself. Although anger and violence were essential within a number of the role-plays, they had to be enacted in predictable ways and could not become real.

Amid these parameters, a range of affects were performed and experienced by role-players with varying past experiences in Iraq. I frequently asked roleplayers if they were emotionally affected by enacting their own deaths so recently after having lived through a war that had taken so many lives. The typical reply invoked a habituation to death because of Iraq's history: "No, we are Iraqi. We are used to it." But some, who had endured the most acute war trauma, such as death threats and near death experiences, noted that simulations could prove emotionally perilous. When a role-player embodies a role with convincing intensity, the others call this 'aīsh bi-dūr, or living in the role. Yet sometimes a roleplayer is entered, or lived by, the role: possessed by it and reliving his or her dangerous wartime past.

During a mock funeral, Sumayya, a role-player who had been kidnapped in Iraq when she worked as an interpreter, had been role-playing an interpreter. Encountering a costume she associated with insurgents in Iraq left her deeply shaken. I asked Hussein what he thought had happened to her and he replied: "She was living it. Her reaction then would be the same as now. She was shaking."

Although such moments of witnessing someone being lived by the role occurred occasionally during my two years of fieldwork, role-players more typically dealt with the simulations with calculated remove. Rather than tumbling into entry points of verisimilitude, they more often deflected, sometimes through laughter. During the simulations, I argue, the seemingly recognizable and real (the referents of the Middle East: war, death) become laughably, uncannily fantastic through repetition and artifice: laughter acts as a response to the gap between alive and dead; moving and frozen; the hyperartifice of simulated Iraq and 
the painful real of an Iraq to which these Iraqis cannot, at present, return. Most crucially, laughter decisively resituates the role-plays as mechanized artifice, enabling role-players to create their own real amid that artifice.

As military architects of the mock villages seek to enact authenticity, they often mire the spaces in artifice, sometimes creating comedic disjunctures for the role-players. Fredric Jameson $(1991,18)$ describes pastiche as an imitation of something idiosyncratic yet "amputated of the satiric impulse. Pastiche is . . . blank parody. . . . A statue with blind eyeballs." In the instance of the mock Middle Eastern village and its inhabitants, the copy is created as pastiche by its fabricators. Yet it is sometimes experienced as parody by those who have been there. Indeed, at the larger training exercises, military contractors furnish a "village in a box," which can come equipped with everything from fake vegetables and Middle Eastern swag (prayer rugs, posters of militia members) to ethnicized corpses, all arranged against the backdrop of a cartoonish mosque dome.

Amid this artifice, role-players have been hired to enact Middle Eastern villagers authentically — not by their own measures, but rather within prescribed military terms. Role-players are asked to be exemplars of their cultures and those cultures must be synchronic, pruned of their excesses and any relationship to the outside: Iraqis, as it were, in a box. However, as previously described, the Iraqis who worked for the American military first as interpreters and contractors in the 2003 Iraq War and subsequently as role-players are a somewhat unique subset of the population; indeed, they are often quite far removed from the U.S. military's imagined characteristics of a prototypical Iraqi. Not only are many of them educated, they are also particularly versed in American culture and critical of Iraqi politics. They typically bear an ambivalent relationship to both countries as they negotiate past accusations, allegiances, and the prospect of assimilation. Many show little trust for outsiders and even less for each other, and because of their dangerous affiliations in wartime, they have learned to chameleon in most circumstances. As they are turned into stereotypes inside an archetypal village, and as they act out wartime precarity so often that their homes and their losses turn into even more estranging archetypes, they laugh.

The machine thus turns out to be made of flesh. Role-players inject new ways of being, in part through laughter, into their performances. Those interjections indicate the limits of a military fantasy that believes human beings can be wholly resourced and turned into technologies. Yet as I will demonstrate in the following section, they may have little impact on the military's training structure itself. 


\section{THE LAUGHSCREAM}

As role-players repetitively embody market-goers, prisoners, beaten wives, mourners, and militants for the training soldiers, the ossified postures, characters, and interactions they stage sometimes trigger laughter-thereby interrupting those postures.

Henri Bergson $(1914,10,25)$ explains that a certain kind of laughter is provoked by "mechanical inelasticity, just where one would expect the wideawake adaptability and the live pliableness of a human being." For Bergson, "really living life should never repeat itself"; practices of stylized repetition risk, for instance, sealing the human face into a machine or a death mask. Ironically, however, such archetypal faces produce laughter, interrupting their tendency toward stasis: "Some faces seem to be always engaged in weeping, others in laughing or whistling, others, again, in eternally blowing an imaginary trumpet, and these are the most comic faces of all." Laughter thus acts not only as a reprieve but also as a partial crack in that mask: eruptions both caused by and capable of interrupting the archetypal and mechanized face.

There is a crescendo of sobs and Arabic in the Crying Room. Each team of soldiers reacts differently to the cacophony, their captain maintaining calm or becoming flushed and anxious. For the soldiers to succeed in this simulation, they must first establish rapport with the mourning women, then notice that the house might be connected to the town militia and procure intelligence. Meanwhile, the hubbub rises in the simulation: sometimes one of the women runs up to a soldier and entreats him furiously in her own dialect of Arabic, which he typically cannot understand. Amid the clamor, the captain tries to build a relationship with the women.

But the role-players have been screaming all day. Amid the ennui of the endless mechanized repetitions, hoarse throats, and the gap between this coffin and the coffins they saw in Iraq, the role-players sometimes stop wailing the classic words of grief. In such moments, muffled laughter can commingle with their cries as a role-player conceals her faces with her veils. In one instance, one role-player shouted in Arabic: "How long until lunch?" Lubna tells me: "Say anything as long as it's in Arabic! Once I yelled: 'I want a hamburger,' forgetting the soldiers would recognize the word, and I clapped a hand over my mouth." Similarly, in the middle of a simulated mass-casualty event, another role-player, Salma, jokingly yelled out the perpetrator: “That's my uncle!"-precipitating suppressed laughter amid the screaming. 
Indeed, the work shifts are long and taxing, as the role-players act out war wounds, their mouths frozen into $O$ s of grief, their voices nearly gone from crying. But wanting the shift to be over, craving a hamburger, and saying it constitutes an injection of the alive, actual body as a retort to the mechanical body. Making a dark joke about one's uncle within a narrative in which all Iraqis are potential adversaries also constitutes a refusal: the uncanny role-play restitches itself into a moment of rebuke. Indeed, Dominic Boyer and Alexei Yurchak (2010, 213) point to the possibility of satire in generating an "alternative aesthetics and practice of political critique." Without overthrowing a political order, such moments of laughter fusing with screaming might do "real political work, fostering the development of new subjectivities" (Bernal 2013, 306). Judith Butler (2006, 127, 169) notes that such subversion may occur "from within the terms of the law," while still offering the potential for the "parodic redeployment of power." The law, in this instance, might be understood as the archetypal face imagined by military scriptwriters, a face required to repeat itself so many times that it becomes mechanical, turning the person into a cultural tool. Indeed, these wartime intermediaries are being asked to enact, without rupture or divergence, a military fantasy of a range of readable and usable Middle Eastern individuals in wartime. Within the training, each character encompasses a recognizable type and a lesson. In the Crying Room, for example, there are mourning mothers and sisters who might be willing to offer intelligence if that made their villages and children safer. The soldiers must establish a relationship with them, evince pathos when they weep, and convince them to offer assistance to the U.S. mission.

In military logics of counterinsurgency, all local individuals in wartime are good guys, bad guys, or fence-sitters. Fence-sitters can be wooed over to the American cause and co-opted as what Hillel Cohen (2010) has called "good Arabs." In this exercise, the women are potentially the good Arabs: the soldiers' success depends on their co-optability. In this constellation, the women must be willing to appreciate the rightness and justness of the American cause, the appeal toward a universal good, posited as implicit in the U.S. occupation of the mock Middle Eastern country.

That archetype marginalizes the much more complex position and personal and familial stakes for the actual Middle Eastern individual in the middle of this geopolitical and ideological battle. In the scenario, the men of the house are affiliated with the militia. For the U.S. soldiers to be effective, they must procure social information and intelligence from the women. Yet for those women to share information for them means risking everything and potentially finding them- 
selves accused of betrayal by their own families. Given their own wartime histories, many of the Iraqi role-players are intimately familiar with those stakes.

Perhaps at least in part for that reason, rather than remaining wholly compressed into a military archetype, something else happens. Lubna displaces the archetype of mourning mother/good Arab, and instead yells out that she is hungry. Salma, meant to act out an Iraqi woman potentially affiliated with the terrorists, jokes about her uncle. These momentary eruptions in which laughter and screaming commingle are caused by the act of embodying the archetypal facebut they also interrupt it. Just when machine-like repetition seems to refute the variability of the human being, living life itself returns in full force. Through laughter-infused wailing, role-players find momentary means to comment on that artifice, creating a rebuke both to being turned into automated archetypes and to inhabiting wartime wounds. The outburst is something akin to Donna Goldstein's (2003) "laughter out of place," where humor forms a retort to suffering and precarity. Through laughter, the role-players insist on a changed form of being alive after war's injuries, effectively refusing to robotically enact the perfectly cooptable intermediary. One role-player, Hussein, coined a name for this subversive affect. He described how role-players had reacted during a simulated funeral: "They brought him on the stretcher. Some people were screaming and moaning. Others were laughscreaming."

In this moment of affective surplus, the role-players distance themselves from embodying military archetypes and becoming slotted into the violent fixity of military categories. The person knows or feels more than the military narrative of their experience can accommodate, exceeding the constricted functions prescribed for a hired cultural tool. Additionally, the laughscream acts as a refusal to be lived by the role and the role-players' fraught wartime pasts. For those accused of betrayal and marginalized by their compatriots, pursued by Iraqi militias and not always trusted by the U.S. soldiers whom they worked for, that past is painful. As one role-player explained, reflecting on the harshness many Iraqis had endured: "We are turned inside out. At the same time, we can laugh and cry." Indeed, for Iraqis who worked with the U.S. military, it is presently prohibitively dangerous to return to their former home, particularly amid the ascendance of the Islamic State. Meanwhile, due to their wartime choices, many now negotiate ongoing ambivalence and feel stranded between nations: although they were frequently ejected to the peripheries of their countries for working with the Americans, many strongly identify with Iraq and are ill at ease with full assimilation in America. As they continue to work for the U.S. military, some 
conceal that work from their families in Iraq, grappling with how they might be perceived. Amid these tensions, the laughscream functions in part as an actor, an agentive vector out.

Laughter rises to confirm that, for the role-players at least, the Iraq of the simulation is not the Iraq of their homeland. As fake guns sound, role-players repeat themselves, becoming increasingly estranged from the original object. Yet, through laughter, the archetypal and mechanical face of country and person give way to Iraqis who live impossibly hybrid and ambivalent lives in the United States to which they have aligned at such great cost. In the parodic redeployment of power as Judith Butler has conceived it, the mechanical performance of death becomes a complexly subversive act that momentarily insinuates life into the playing of a role.

The role-players' laughter matters - perhaps it can even be described as selfpreservation for them - but what does this affective moment mean in the context of the military project? Arguably, the military structure is neither undermined nor reinforced through affect: rather, it continues seemingly unchanged. Even as role-players experience incongruities in Middle Eastern representations, or even as they laugh, little appears to change for the users of that cultural technology, the training soldiers. In my observation, the soldiers seem not to notice such momentary disjunctures and are quickly shuffled onward to the next simulation: that is, feelings do not appear to structure anything. When role-players laugh briefly, they veil their faces and the moment passes. When Salma yelled that her uncle was a terrorist, I looked at her wide-eyed, laughed briefly, and the simulation continued unchanged. Meanwhile, when role-players experience epistemological surfeits, they often keep these moments to themselves, unwilling to risk their jobs if they disagree with military supervisors. As Heidegger $(1996,68)$ notes, a tool only truly "breaks" when it becomes "conspicuous" to its user. But these moments of disjuncture were not readily apparent to the soldiers.

While acknowledging the potential agentive importance of such moments for the role-players themselves, I propose that there may be little impact on the military structure itself - or on the training soldiers, who are a step removed from these moments of surplus experienced by the role-players. Reversing Raymond Williams's classic formulation, Analiese Richards and Daromir Rudnyckyj (2009, 7) ask "not what structures feelings but what feelings structure." Conversely, I offer a case study where feelings may offer an altered possibility for those experiencing them, but may structure little within the military training itself. Theoretically and on an existential level, such affective interruptions throw 
into question the contradictory assemblage of the human technology, and the extent to which human beings can be resourced in this manner. However, I contend that ultimately these individuals, harnessed as cultural tools, largely remain working within the terms forged for them. That is, their affective overflow may bear little relationship to the continuance of the military training project, as soldiers go on rehearsing the operationalization of culture.

Bill, a retired American soldier involved in the trainings, explained: "Unless something interrupts the goals of the training, then whatever is done by the roleplayers, who gives a shit?" In his opinion, it seemed unlikely that the training soldiers even noticed such moments of disjuncture: "Think about where their mind is [sic] at. You think they're going to catch those little nuances? They could not care less. Those things [the Iraqis saying something extra or laughing for a minute] have no value.” John, another soldier involved in crafting and supervising trainings, agreed that moments of role-player disjuncture did not interrupt the training, but proposed that such instances might "in some cases reinforce training objectives." Moments of puzzlement might cause the training soldier to "wonder if he had redirected the cultural exchange in an uncustomary way." However, he too concluded, by way of a question, that "if a tree falls in the woods and no one is around to hear it, does it make a sound?"

I asked John about the possible relevance of role-players' internal experiences in the role-play. I described the periodic jokes within the simulation, noting that they were particularly ironic and complicated if one knew the role-players' backgrounds. Some struggled with working for the U.S. military, given their mixed feelings about American interventions in the Middle East. Some even hid the work from their families back home. John found my observations tangential: "If there's trauma behind it or it's just sass, who cares? What's the 'so what?' It's surreal, I'll give you that, but that may be all." Bill explained: "All that matters in the training is the soldiers get to practice rapport. All the rest is background noise."

Within this logic, the training mechanism essentially remains undisturbed for the soldiers. Indeed, we might conclude that the role-players might be used seamlessly as wartime technologies, without disrupting military systems or notions about others in the world. The soldiers enter the Crying Room, enact empathy for the mourning women, extract information with varying degrees of success, walk into the back room and find the weapons, confirming that the women are exactly who they suspected all along. Reset. In the training machines of the 
cultural turn, both the Middle Eastern role-players and the soldiers are tools, part of a military system that resources humans in the service of empire.

\title{
CONCLUSION
}

Are affective forces capable of overthrowing discursive regimes and initiating new modes of living in the world (see Guattari 1995)? Without negating such momentary agentive possibilities for the individual, I follow recent anthropologists' reminders that we must locate affect within power relations, inequalities, and violence (Biehl 2013; Adams 2013; Berg and Ramos-Zayas 2015). In this instance, affective maneuvers recuperate subjectivity; they do not modify structures.

Still, a last ironic kink persists. Military cultural trainings, at bottom, seek to prepare the soldier "for the real thing." Yet the simulations embody a charged irony, such that those who are militarized as human technologies, in part, to be themselves, know that they are anything but. This gap suggests that the military edifice itself is perhaps out of order, even on its own terms. Namely, a training mechanism to render human terrain legible and containable, which effaces its own moments of excess, may well encounter its own limits when the soldiers arrive in the war zone. As one interlocutor, who problematized the fixed categories of some of the cultural trainings, cautioned by reading me this line from a William Meredith (1987, 76) poem: "Things are not orderly here, no matter what they say." The laughscream is the hiccup in the machinery, one that may be imperceptible at the time of the training, but that may signal the structure's potential breakability in the war beyond.

\begin{abstract}
In a new contribution to contemporary scholarship on war, I explore the epistemological and affective labors outsourced to individuals I call human technologies: populations of local wartime intermediaries and cultural role-players employed by the U.S. military as embodied repositories of Middle East knowledge. Drawing on fieldwork across the United States, this study focuses on the largely unexamined ethnographic spaces of U.S. military predeployment simulations in mock Middle Eastern villages. I focus on Iraqis who first worked for the U.S. military in Iraq as interpreters and then as role-players within predeployment simulations in the United States. Through a close examination of the wartime labors of these individuals, this study illuminates how the intrinsic contradiction in the term human technology - the turning of person into machine for a singular use, foreclosing other forms of being and becoming - plays out on the ground. I demonstrate how the ironic disjuncture
\end{abstract}


between military prescriptions for authenticity and role-players' experiences of inauthenticity generates moments of affective rupture for those hired to embody their cultures. I argue that a charged tension manifests itself in the training apparatus: on an epistemological level, even as they experience excess, role-players work to make the simulations "look good" to retain their jobs. Meanwhile, that excess manifests itself in affective overflow - in particular, one form that a role-player called "the laughscream." I contend that such moments of affective excess create a momentary reprieve for role-players, while typically not disturbing the military structure. The role-players' laughter existentially negates the possibility that human beings can be tools, while permitting them, in practice, to be used as tools. [militarism; affect; laughter; simulation; United States; Middle East]

\section{NOTES}

Acknowledgments My tremendous appreciation goes, first, to my writing group, Stephanie Savell and Jennifer Tucker, and also to Elaine Stone, for having so generously read many iterations of this article. My huge gratitude to Dominic Boyer, the anonymous peer reviewers, Marcel LaFlamme, and Petra Dreiser at Cultural Anthropology, who all contributed to the trajectory of this article. Thank you especially to my advisors and mentors at Columbia University: Nadia Abu El-Haj, Brinkley Messick, and Marilyn Ivy. And thank you to the many other friends and colleagues who offered essential input along the way: Kenneth MacLeish, Zoë Wool, Catherine Trundle, Emily Sogn, and Can Açiksöz at the Military Bodies Workshop at the University of Michigan, as well as Sameen Gauhar, Amelia Boulware, Allison Titus, and John Paul Molenda. My deep gratitude goes as well to my Iraqi and American interlocutors in the field. The research presented here was funded by the Wenner-Gren Foundation, the Osmundsen Initiative, and the Social Science Research Council's International Dissertation Research Fellowship Program.

1. The data for this article is drawn from observing cultural training exercises at three military bases and one military academy in the United States, which largely focused on counterinsurgency-related preparation, as well as interviews with Iraqis in diaspora throughout the United States and Jordan. I relied on participant-observation and conversations, as well as on more than ninety interviews with a combination of military personnel and the Iraqis who worked with U.S. soldiers or companies. I was also occasionally cast in role-plays. Interviews with role-players typically occurred in Arabic. Access to the military spaces came incrementally and was likely born of a particular geopolitical moment: the military was strategically engaged with culture, the province of my own academic discipline. I located myself as an outside observer interested in future academic jobs who did not plan to work for the military. My goal in this article is not to comment on any specific training exercise, protocol, or unit. Instead of closely following one training exercise at one base, I chose to look at patterns at multiple bases across a range of different military units. This also allowed me to obscure the identities of my interlocutors and other particularities.

2. Trainees typically use interpreters within simulations, and practice working with interpreters is seen as essential. Although they have typically received some language training by this juncture (of varying duration, depending on rank and mission), soldiers I observed typically did not appear to understand the role-players (who were speaking in their own dialects), nor did they try to converse with them in Arabic within or outside simulations, but generally relied on their interpreters.

3. A range of programs facilitated the entry of Iraqis into the United States. In 2007, at the height of sectarian violence, only 6,000 Iraqi refugees had been admitted to the United States. Larger-scale processing was initiated at that juncture, focusing on the 
especially vulnerable, such as those impacted by sectarian violence or affiliated with the U.S. government. Between 2007 and 2013, 84,902 Iraqi refugees were admitted via the U.S. Refugee Admission Program. The Special Immigrant Visa Program, which stipulated the admission of 5,000 affiliated Iraqis each year between 2008 and 2012, rarely met quotas, in fact issuing fewer than 5,000 visas during the entire period.

4. In 2007, Patrick Porter (2007) described a "cultural turn" in the military's field of counterinsurgency studies. The term entered the anthropological lexicon soon thereafter; see Gregory 2008.

5. The metaphor of the human machine dates back to Aristotle, was developed by René Descartes, and took on various permutations, from Taylorism to the Marxist critique of man's estrangement from his own labor-power. The conceit of the human technology is inspired by this genealogy, as well as Heidegger's (1982) pivotal essay on technology.

6. This number is probably on the low side; a report from the Congressional Budget Office (2008) estimated that over seventy thousand Iraqis worked as contractors alone.

\section{REFERENCES}

Adams, Vincanne

2013 Markets of Sorrow, Labors of Faith: New Orleans in the Wake of Katrina. Durham, N.C.: Duke University Press.

American Anthropological Association Executive Board

2007 "Statement on the Human Terrain System Project." October 31. http:// www.americananthro.org/ConnectWithAAA/

Content.aspx?ItemNumber $=1626$.

Asad, Talal

1983 “Anthropological Conceptions of Religion: Reflections on Geertz." Man N.S. 18, no. 2: 237-59. https://doi.org/10.2307/2801433.

1986 "The Concept of Cultural Translation in British Social Anthropology." In Writing Culture: The Poetics and Politics of Ethnography, edited by James Clifford and George

E. Marcus, 141-64. Berkeley: University of California Press.

Berg, Ulla D., and Ana Y. Ramos-Zayas

2015 "Racializing Affect: A Theoretical Proposition." Current Anthropology 56, no. 5: 654-77. https://doi.org/10.1086/683053.

Bergson, Henri

1914 Laughter: An Essay on the Meaning of the Comic. Translated by Cloudesley Brereton and Fred Rothwell. New York: Macmillan. Originally published in 1900.

Berlant, Lauren

1997 The Queen of America Goes to Washington City: Essays on Sex and Citizenship. Durham, N.C.: Duke University Press.

Bernal, Victoria

2013 "Please Forget Democracy and Justice: Eritrean Politics and the Powers of Humor." American Ethnologist 40, no. 2: 300-309. https://doi.org/10.1111/ amet. 12022 .

Biehl, João

2013 Vita: Life in a Zone of Social Abandonment. Berkeley: University of California Press. Boyer, Dominic, and Alexei Yurchak

2010 "American Stiob: Or, What Late-Socialist Aesthetics of Parody Reveal about Contemporary Political Culture in the West." Cultural Anthropology 25, no. 2: 179-221. https://doi.org/10.1111/j.1548-1360.2010.01056.x.

Butler, Judith

2006 Gender Trouble: Feminism and the Subversion of Identity. New York: Routledge.

Cohen, Hillel Originally published in 1990 .

2010 Good Arabs: The Israeli Security Agencies and the Israeli Arabs, 1948-1967. Translated by Haim Watzman. Berkeley: University of California Press. Originally published in 2006. 
Congressional Budget Office

2008 “Contractors' Support of U.S. Operations in Iraq.” Prepared by Daniel Frisk and R. Derek Trunkey, under the supervision of J. Michael Gilmore and Matthew Goldberg. https://www.cbo.gov/publication/41728.

Davis, Rochelle

2010 “Culture as a Weapon System.” Middle East Report, no. 255: 8-13. http:// www.merip.org/mer/mer255/culture-weapon.

Der Derian, James

2001 Virtuous War: Mapping the Military-Industrial-Media-Entertainment Network. Boulder, Colo.: Westview Press.

Forte, Maximilian C.

2011 "The Human Terrain System and Anthropology." Public Anthropology 113, no. 1: 149-53. https://doi.org/10.1111/j.1548-1433.2010.01315.x.

Goldstein, Donna M.

2003 Laughter Out of Place: Race, Class, Violence, and Sexuality in a Rio Shantytown. Berkeley: University of California Press.

Graham, Stephen

2007 "War and the City." New Left Review 44: 121-32. https://newleftreview.org/

Gregory, Derek II/44/stephen-graham-war-and-the-city.

2008 "'The rush to the intimate': Counterinsurgency and the Cultural Turn." Radical Philosophy 150: 8-23. https://www.radicalphilosophy.com/article/"the-rushto-the-intimate'.

Guattari, Félix

1995 Chaosmosis: An Ethico-Aesthetic Paradigm. Translated by Paul Bains and Julian Pefanis. Bloomington: Indiana University Press. Originally published in 1992.

Gutmann, Matthew, and Catherine Lutz

2010 Breaking Ranks: Iraq Veterans Speak Out Against the War. Berkeley: University of California Press.

Heidegger, Martin

1982 "The Question Concerning Technology." In The Question Concerning Technology and Other Essays, translated by William Lovitt, 3-35. New York: Harper Collins. Originally published in 1954 .

1996 Being and Time. Translated by Joan Stambaugh. Albany: State University of New York Press. Originally published in 1927.

Jameson, Fredric

1991 Postmodernism, or, the Cultural Logic of Late Capitalism. Durham, N.C.: Duke University Press.

Kelly, John D., Beatrice Jauregui, Sean T. Mitchell, and Jeremy Walton, eds.

2010 Anthropology and Global Counterinsurgency. Chicago: University of Chicago Press.

Lutz, Catherine

2001 Homefront: A Military City and the American Twentieth Century. Boston: Beacon Press.

MacLeish, Kenneth T.

2012 "Armor and Anesthesia: Exposure, Feeling, and the Soldier's Body." Medical Anthropology Quarterly 26, no. 1: 49-68. https://doi.org/10.1111/j.15481387.2011.01196.x.

2015 Making War at Fort Hood: Life and Uncertainty in a Military Community. Princeton,

Marx, Karl

N.J.: Princeton University Press. Originally published in 2013.

2011 Capital, Volume 1: A Critique of Political Economy. Translated by Samuel Moore and Edward Aveling. Mineola, N.Y.: Dover Publications. Originally published in 1867.

Masco, Joseph

2014 The Theater of Operations: National Security Affect from the Cold War to the War on Terror. Durham, N.C.: Duke University Press. 
Massumi, Brian

1996 “The Autonomy of Affect." In Deleuze: A Critical Reader, edited by Paul Patton, 217-39. Malden, Mass.: Blackwell.

Mazzarella, William

2009 "Affect: What is it Good for?" In Enchantments of Modernity: Empire, Nation, Globalization, edited by Saurabh Dube, 292-308. New York: Routledge.

McFate, Montgomery

2005 "The Military Utility of Understanding Adversary Culture." Joint Force Quarterly, no. 38: $42-48$.

Meredith, William

1987 “Poem about Morning." In Partial Accounts: New and Selected Poems, 76. New York: Knopf.

Porter, Patrick

2007 "Good Anthropology, Bad History: The Cultural Turn in Studying War." Parameters, Summer: 45-58. http://strategicstudiesinstitute.army.mil/pubs/ parameters/Articles/07summer/porter.htm.

Price, David

2009 "A Better Way to Kill? Human Terrain Systems, Anthropologists, and the War in Afghanistan." Counterpunch, December 1. http://www.counterpunch.org/ 2009/12/01/human-terrain-systems-anthropologists-and-the-war-inafghanistan.

Richard, Analiese, and Daromir Rudnyckyj

2009 "Economies of Affect." Journal of the Royal Anthropological Institute 15, no. 1:57-

Said, Edward 77. https://doi.org/10.1111/j.1467-9655.2008.01530.x.

1978 Orientalism. London: Routledge and Kegan Paul.

Sartre, Jean-Paul

2008 "What is a Collaborator?" In The Aftermath of War, translated by Chris Turner, 41-64. New York: Seagull. Originally published in 1949.

Stewart, Kathleen

2005 “Cultural Poesis: The Generativity of Emergent Things.” In The SAGE Handbook of Qualitative Research, 3rd edition, edited by Norman K. Denzin and Yvonna S.

Stoler, Ann Laura Lincoln, 1027-42. Thousand Oaks, Calif.: SAGE.

2002 Carnal Knowledge and Imperial Power: Race and the Intimate in Colonial Rule. Berkeley: University of California Press.

Stone, Nomi

2016 “Human Technologies in the Iraq War.” PhD dissertation, Columbia University. Virilio, Paul

1989 War and Cinema: The Logistics of Perception. Translated by Patrick Camiller. New Wool, Zoë H.

York: Verso. Originally published in 1984

2015 After War: The Weight of Life at Walter Reed. Durham, N.C.: Duke University Press. 